\title{
Synthesis of $\mathrm{Fe}_{2} \mathrm{O}_{3} /$ Graphene Composite Anode Materials with Good Cycle Stability for Lithium-ion Batteries
}

\author{
Lilai Liu*, Zhiwei Song, Juan Wang, Lu Shen, Bangdi Tu, Sucheng Wang, Daorui Mao \\ College of Environmental and Chemical Engineering, Heilongjiang University of Science and \\ Technology, Harbin 150022, China \\ *E-mail: 1llusth@163.com
}

doi: $10.20964 / 2016.10 .14$

Received: 3 April 2016 / Accepted: 26 July 2016 / Published: 6 September 2016

$\mathrm{Fe}_{2} \mathrm{O}_{3}$ /graphene composite anode materials have been successfully synthesized by a PVP-assisted homogeneous precipitation method. The size of $\mathrm{Fe}_{2} \mathrm{O}_{3}$ nanoparticles on the surface of graphene sheets was less than $35 \mathrm{~nm}$. $\mathrm{Fe}_{2} \mathrm{O}_{3}$ nanoparticles and graphene sheets formed a network structure. Electrochemical properties were evaluated in two-electrode cells versus metallic lithium. The $\mathrm{Fe}_{2} \mathrm{O}_{3}$ /graphene composite exhibited excellent electrochemical lithium storage performances. The first discharge and charge capacities were 1600 and $1053 \mathrm{~mA} \mathrm{~h} \mathrm{~g}^{-1}$ at a current density of $100 \mathrm{~mA} \mathrm{~g}^{-1}$, and the first coulomb efficiencies was $65.8 \%$. The reversible specific capacity remained $893 \mathrm{~mA} \mathrm{~h} \mathrm{~g}^{-1}$ and the capacity retention was $84.8 \%$ after 100 cycles.

Keywords: $\mathrm{Fe}_{2} \mathrm{O}_{3}$; graphene; composite; anode; lithium-ion batteries

\section{FULL TEXT}

(C) 2016 The Authors. Published by ESG (www.electrochemsci.org). This article is an open access article distributed under the terms and conditions of the Creative Commons Attribution license (http://creativecommons.org/licenses/by/4.0/). 